\title{
UKURAN PERUSAHAAN, UMUR PERUSAHAAN, PERTUMBUHAN PENJUALAN, KEPEMILIKAN MANAJERIAL DAN PENGHINDARAN PAJAK
}

\author{
TRISNINIK RATIH WULANDARI'¹ (trisninikrw@staff.uns.ac.id) \\ LEO JOKO PURNOMO ${ }^{2}$
}

${ }^{1}$ Program Studi D3 Perpajakan, Sekolah Vokasi, Universitas Sebelas Maret, Indonesia

${ }^{2}$ Program Studi Akuntansi, Fakultas Ekonomi dan Bisnis, Universitas Sebelas Maret, Indonesia

\begin{abstract}
AB S TRACT
Companies avoid tax in order to minimize the company's tax burden by utilizing loopholes in tax regulations. This research investigate the influence firm size, firm age, sales growth, and managerial ownership to tax avoidance. The population of this research is Non Service companies listed on the Indonesian Stock Exchange for period 2014-2018.The number of samples used in this study were 365 samples based on the purposive sampling method. The data analysis technique in this study is quantitative analysis by using multiple linier regression method. The results of this study indicate that partially the variable firm size, firm age, and sales growth have a positive affect on tax avoidance in sample companies, while the managerial ownership do not affect on tax avoidance in sample companies. A limitation in this study is the ETR proxy which cannot distinguish between tax avoidance, government tax preferences, or tax lobbying activities. In addition, the measurement of profit based on accounting income cannot describe tax avoidance directly.
\end{abstract}

Keywords: Tax avoidance, firm size, age, sales growth, and managerial ownership

Perusahaan melakukan penghindaran pajak dalam rangka meminimalkan beban pajak perusahaan melalui celah yang terdapat dalam peraturan perpajakan. Penelitian ini bertujuan untuk memberikan bukti empiris pengaruh ukuran perusahaan, umur perusahaan, pertumbuhan penjualan, dan kepemilikan manajerial terhadap penghindaran pajak. Populasi penelitian ini adalah perusahaan nonjasa yang terdaftar di Bursa Efek Indonesia pada tahun 2014-2018. Jumlah sampel yang digunakan dalam penelitian ini sebanyak 365 sampel berdasarkan metode purposive sampling. Metode analisis data dalam penelitian ini adalah analisis kuantitatif dengan menggunakan analisis regresi linear berganda. Hasil penelitian ini menunjukkan bahwa ukuran perusahaan, umur perusahaan, pertumbuhan penjualan berpengaruh positif terhadap penghindaran pajak, sedangkan kepemilikan manajerial tidak berpengaruh terhadap penghindaran pajak. Keterbatasan dalam penelitian ini adalah proksi Effective Tax Rate (ETR) yang tidak dapat membedakan antara kegiatan penghindaran pajak, preferensi pajak pemerintah, atau lobi pajak. Selain itu, pengukuran laba berdasarkan laba akuntansi tidak dapat menggambarkan penghindaran pajak secara langsung.

Kata kunci: Penghindaran Pajak, Ukuran Perusahaan, Umur Perusahaan, Pertumbuhan Penjualan, kepemilikan Manajerial

\section{PENDAHULUAN}

Perpajakan merupakan sektor penyumbang pendapatan terbesar bagi negara. Kontribusi sektor perpajakan pada tahun 2018 mencapai angka Rp1.521,4 triliun atau sebesar 78,32 \% dari total realisasi pendapatan negara (Direktorat Jenderal Pajak, 2018). Sektor pajak memiliki peran strategis bagi peningkatan pendapatan negara. Penerimaan pajak yang tidak sesuai target akan berdampak pada tidak tercapainya pendapatan negara. Pada tahun 2018 sumber uta- ma pendapatan pajak berasal dari Pajak Penghasilan Non Migas (PPh Non Migas) sebesar 52\% yang didominasi oleh pendapatan PPh Badan. Tercatat dari tahun 20142018 rata-rata kontribusi PPh badan sebesar 33.15 \% per tahun dari total penerimaan PPh Non Migas. Kontribusi yang besar menjadikan PPh Badan sebagai objek potensial untuk mencapai target pendapatan pajak dan otoritas pajak harus mampu mengoptimalkan pengelolaan PPh Badan (Direktorat Jenderal Pajak, 2018). 
Sampai saat ini penerimaan pajak di Indonesia belum tercapai secara optimal. Tahun 2018 realisasi penerimaan pajak bertahan di angka Rp 1.521,4 triliun atau sebesar 92,24\% dari target. Selain itu, kondisi perpajakan di Indonesia juga tercermin dalam besarnya angka tax ratio. Tax ratio dihitung dengan membagi jumlah penerimaan pajak dibagi dengan Produk Domestik Bruto (PDB). Pertumbuhan tax ratio dari tahun 2014-2018 belum mengalami pergerakan yang signifikan dan belum mencapai angka 12,5\% (Direktorat Jenderal Pajak, 2018). Sementara menurut Denny Darusalam Tax Center (DDTC) Fiscal Research (2017) untuk negara dengan pendapatan menengah ratarata seharusnya memiliki tax ratio di angka $16 \%-18 \%$.

Besarnya angka tax ratio di Indonesia dipengaruhi oleh beberapa faktor yaitu, kebijakan perpajakan, efektivitas pemungutan pajak, insentif dan pengecualian pajak yang diberikan kepada pelaku ekonomi dan masyarakat, serta adanya penghindaran dan penggelapan pajak. Hal yang sama disampaikan oleh Yustinus Prastowo dalam Media Keuangan Transparansi Informasi Kebijakan Fiskal (2019) yang menyatakan bahwa terdapat empat penyebab rendahnya tax ratio di Indonesia, yaitu rendahnya tingkat kepatuhan pajak, tingginya hard to tax sector, keterbatasan regulasi dan instrumen administrasi dalam perkembangan ekonomi digital, dan praktik penghindaran pajak yang semakin marak dilakukan.

Penghindaran pajak merupakan perbuatan yang legal karena tidak melanggar peraturan perpajakan dengan cara mengurangi jumlah pajak menggunakan kelemahan peraturan (Hutagoal, 2007). Meskipun bersifat legal penghindaran pajak merupakan hal yang tidak diinginkan oleh negara karena dapat menimbulkan penurunan dalam penerimaan negara. Menurut (Stiglitz, 1986) terdapat tiga karakteristik penghindaran pajak. Pertama, penghindaran pajak dapat dilakukan karena adanya kesempatan bagi wajib pajak untuk menunda pembayaran pajak. Kedua, adanya perbedaan tarif antara pajak penghasilan dengan transaksi khusus. Terakhir, memanfaatkan berbagai aspek kelemahan dari undang-undang perpajakan khususnya terkait perbedaan karakteristik transaksi keuangan. Tujuan perusahaan melakukan penghindaran pajak adalah untuk menekan besarnya pembayaran pajak dan meningkatkan laba setelah pajak. Peningkatan laba akan berdampak positif terhadap nilai perusahaan dan kompensasi yang diterima manajer akan bertambah karena dianggap mampu menjalankan tanggung jawabnya (Charisma \& Dwimulyani, 2019).

Kasus penghindaran pajak merupakan salah satu fenomena yang terus diteliti sampai saat ini. Hal ini sejalan dengan banyaknya perusahaan yang terindikasi melakukan penghindaran pajak, baik perusahaan multinasional maupun perusahaan domestik. Umumnya perusahaan menggunakan skema Base Erosion and Profit Shifting (BEPS) sebagai upaya untuk menghindari atau mengurangi kewajiban pajaknya pada suatu negara (Permata, Nurlaela, \& Masitoh, 2018). Skema BEPS merupakan upaya memanfaatkan celah kelemahan dalam peraturan perpajakan (domestik) dan perbedaan sistem perpajakan antar negara. Perusahaan dapat mengalihkan keuntungan perusahaannya pada negara lain yang memiliki tarif pajak yang lebih rendah atau negara-negara yang terkenal dengan tax heaven melalui transfer pricing (Darussalam, 2017).

Salah satu perusahaan yang melakukan penghindaran pajak melalui aktivitas transfer pricing adalah kasus PT Adaro Energy Tbk (ADRO). Menurut Global Witness dalam laporan yang berjudul Taxing Times for Adaro yang rilis pada 4 Juli 2019, Adaro diduga telah mengalihkan keuntungan perusahaan melalui anak perusahan Coaltrade Service Internasional yang terletak di negara tax heaven. Transaksi yang dilakukan Adaro diduga telah dilakukan sejak 2009-2017 dengan kerugian negara mencapai USD 14 juta tiap tahunnya. Kasus penghindaran pajak tersebut bukan pertama bagi Adaro, pada tahun 2008 Adaro juga pernah diindikasikan melakukan penghindaran pajak melalui transfer pricing dengan perusahaan yang terafiliasi di Singapura. 
Fenomena yang terjadi di atas merupakan kasus penghindaran pajak yang muncul ke publik. Faktanya masih banyak perusahaan yang belum terdeteksi dalam melakukan penghindaran pajak. (Setiaji, 2019). Menurut beberapa kasus pajak yang terjadi, terdapat beberapa faktor yang mempengaruhi perusahaan dalam melakukan penghindaran pajak salah satunya adalah ukuran perusahaan, umur perusahaan, pertumbuhan penjualan dan kepemilikan manajerial.

Ukuran perusahaan memiliki peran dalam pemenuhan kewajiban pajak perusahaan. Perusahaan yang masuk dalam kategori besar akan memiliki sumber daya yang lebih besar dan tentu akan menghasilkan beban pajak yang lebih besar juga sehingga perusahaan berupaya untuk mengelola beban pajaknya dengan efisien (Kurniasih d\& Sari, 2013). Perusahaan yang besar dan kompleks mempunyai banyak celah yang dapat digunakan untuk melakukan penghindaran pajak, seperti menggunakan metode akuntansi untuk menangguhkan laba saat ini pada periode mendatang untuk memperoleh beban pajak yang lebih rendah. Fenomena ini sejalan dengan hasil penelitian yang dilakukan oleh Silvia (2017), Wijayanti \& Samrotun (2016), dan Darmawan \& Sukarta (2014) yang memperoleh hasil bahwa ukuran perusahaan berpengaruh negatif terhadap Efective Tax Rate (ETR) atau terjadi pemghindaran pajak yang agresif. Sedangkan penelitian yang dilakukan oleh Nugraheni \& Pratomo (2018) dan Permata et al. (2018) menunjukkan bahwa ukuran perusahaan tidak berpengaruh terhadap ETR .

Selain ukuran perusahaan, faktor yang dapat memengaruhi penghindaran pajak adalah umur perusahaan. Umur perusahaan menunjukkan berapa lama perusahaan bertahan dan mampu bersaing di dunia bisnis. Umur perusahaan diukur sejak perusahaan terdaftar di BEI sampai laporan tahunan diterbitkan (Ihyaul, 2009:203). Menurut penelitian yang dilakukan oleh Loderer \& Waelchli (2010) menjelaskan bahwa perusahaan yang lebih lama berdiri akan menjadi tidak efisien seiring berjalannya waktu. Kondisi tersebut akan mendorong perusahaan untuk melakukan efisiensi atas biaya yang ditanggung perusahaan, termasuk efisiensi beban pajak perusahaan. Hasil penelitian yang dilakukan Dewinta \& Setiawan (2016) dan Silvia (2017) mendapatkan hasil bahwa umur perusahaan berpengaruh positif terhadap penghindaran pajak dan nilai ETR yang rendah. Sedangkan penelitian Setianti (2019) dan Permata et al. (2018) menyatakan bahwa umur perusahaan tidak berpengaruh terhadap ETR.

$\begin{array}{lrr}\begin{array}{c}\text { Pengalaman } \\ \text { perusahaan dan }\end{array} \text { dalam } & \text { keahlian } \\ \text { melakukan }\end{array}$ penghindaran pajak juga bisa dilihat dari pengelolaan tingkat penjualan. Pertumbuhan penjualan berhubungan dengan pengelolaan modal kerja. Semakin tinggi tingkat penjualan maka aset dan modal yang dikelola juga semakin besar sehingga celah untuk melakukan penghindaran pajak juga lebih besar (Dewinta \& Setiawan, 2016). Semakin tinggi tingkat penjualan maka laba yang diperoleh perusahaan juga akan semakin besar begitu juga dengan tanggungan pajaknya. Fenomena tersebut mendorong perusahaan untuk mengelola kewajiban pajaknya sehingga beban pajak yang dibayarkan menjadi rendah. Kondisi tersebut didukung oleh penelitian Tristianto \& Oktaviani (2016) dan Purwanti \& Sugiyarti (2017) yang menyimpulkan bahwa pertumbuhan penjualan berpengaruh terhadap ETR. Hasil yang berbeda diperoleh dari penelitian Oktaviyani \& Munandar (2017), dan Swingly \& Sukartha (2015) yang menemukan bahwa variabel pertumbuhan penjualan tidak mempunyai pengaruh terhadap ETR perusahaan.

Penghindaran pajak juga dimungkinkan terjadi dikarenakan faktor tata kelola perusahaan, salah satunya adalah kepemilikan manajerial. Kepemilikan manajerial merupakan persentase kepemilikan saham manajemen terhadap jumlah saham yang beredar (Munisi, Hermes \& Randøy, 2014). Keberadaan saham manajerial diharapkan mampu menjadi penengah dalam masalah keagenan antara agent dan principal. Kepemilikan manajerial mendorong pihak 
manajemen untuk lebih berhati-hati dalam pengambilan keputusan karena keputusan tersebut akan berdampak langsung bagi perusahaan sekaligus dirinya sendiri sebagai pemilik saham perusahaan. Menurut Gaaya, Lakhal \& Lakhal (2017) kepemilikan saham oleh manajemen dapat menurunkan tingkat penghindaran pajak dikarenakan keputusan yang diambil akan berdampak terhadap entitas yang dimilikinya dan dapat mengurangi kecenderungan manajemen dalam mementingkan kepentingan diri. Hal tersebut sesuai dengan penelitian Charisma \& Dwimulyani (2019) dan Pramudito \& Sari (2015) yang menyatakan kepemilikan manajerial memiliki pengaruh terhadap penghindaran pajak. Sedangkan penelitian Mahulae, Pratomo \& Nurbaiti (2016), Hadi \& Mangoting (2014) menyatakan bahwa kepemilikan manajerial tidak berpengaruh terhadap penghindaran pajak.

Berdasarkan penelitian yang sudah dilakukan oleh peneliti-peneliti terdahulu masih banyak terdapat perbedaan hasil penelitian. Penelitian-penelitian terdahulu umumnya menggunakan data perusahaan manufaktur, sedangkan untuk penelitian ini menggunakan data seluruh perusahaan non-jasa (perusahaan pertanian, pertambangan, dan manufaktur) yang terdaftar di Bursa Efek Indonesia (BEI) selama tahun 2014 sampai dengan 2018. Selain itu perbedaan hasil penelitian kemungkinan disebabkan teori yang digunakan dalam penelitian terdahulu menggunakan dasar teori yang berbeda. Pada penelitian ini peneliti menggunakan political power theory untuk menjelaskan pengaruh variabel ukuran perusahaan dengan penghindaran pajak dan Agency Theory type 1 untuk menjelaskan pengaruh variabel umur perusahaan dan pertumbuhan penjualan terhadap penghindaran pajak, yaitu terdapat agency problem antara principal (pemerintah sebagai pihak yang memiliki otoritas pajak) dan agent (perusahaan yang berkewajiban untuk membayar pajak). Agency Theory juga digunakan untuk menjelaskan pengaruh kepemilikan manajerial dengan aktivitas penghindaran pajak yang dilakukan oleh perusahaan, hanya agency problem yang terjadi antara principal dan agent dilihat dari sudut pandang principal adalah pemegang saham dan managemen/ perusahaan sebagai agent.

Tujuan dari penelitian ini adalah untuk memberikan bukti empiris pengaruh ukuran perusahaan, umur perusahaan, pertumbuhan penjualan, dan kepemilikan manajerial terhadap penghindaran pajak pada perusahaan non -keuangan yang terdaftar di BEI. Penelitian ini dapat berguna sebagai bahan pertimbangan bagi investor dalam pengambilan keputusan investasi. Juga memberikan masukan kepada regulator pajak dalam pembuatan aturan perpajakan sehingga dapat meminimalkan penghindaran pajak yang dilakukan oleh perusahaan.

\section{TINJAUAN PUSTAKA DAN PENGEM- BANGAN HIPOTESIS \\ Pengaruh ukuran perusahaan terhadap penghindaran pajak}

Ukuran perusahaan menggambarkan besarnya aset yang dikelola perusahaan. Perusahaan besar memiliki aktivitas dan operasional yang lebih kompleks dibanding perusahaan yang kecil. Menurut Richardson \& Lanis (2007) perusahaan besar berpontensi dalam melakukan penghindaran pajak untuk menurunkan ETR perusahaan yang artinya praktik penghindaran pajak yang dilakukan perusahaan semakin meningkat. Hal tersebut dikarenakan biaya operasional perusahaan yang besar sehingga perusahaan memanfaatkan sumber daya yang dimiliki untuk melakukan perencanaan pajak dengan optimal (political power theory).

Penelitian Dewinta \& Setyawan (2016) memperoleh hasil bahwa ukuran perusahaan berpengaruh negatif terhadap ETR yang berarti ukuran perusahaan memiliki pengaruh positif terhadap penghindaran pajak. Perusahaan menggunakan sumber daya yang dimiliki untuk memaksimalkan kinerja perusahaan dengan cara menekan biaya pajak. Penelitian lain juga dilakukan oleh Silvia (2017), Wijayanti et al. (2016), Darmawan \& Sukarta ( 2014), dan Fatharani (2012) yang 
memperoleh hasil bahwa ukuran perusahaan berpengaruh negatif pada ETR/ berpengaruh positif terhadap penghindaran pajak. Oleh karena itu, hipotesis yang diambil dalam penelitian ini adalah:

H1: Ukuran perusahaan berpengaruh positif terhadap penghindaran pajak

\section{Pengaruh umur perusahaan terhadap penghindaran pajak}

Lamanya jangka waktu operasional perusahaan akan sebanding dengan pengalaman yang diperoleh perusahaan. Perusahaan yang sudah lama berdiri memiliki kemampuan lebih dalam terhadap pengolahan informasi keuangan dan lebih mampu mengatasi berbagai hambatan yang terjadi (Silvia, 2017). Perusahaan menggunakan pengalaman dan celah dalam peraturan untuk mengelola beban pajak sehingga kewajiban pajak perusahaan menjadi rendah. Dilihat dari Agency Theory, terjadi agency problem antara principal dan agent. Perusahaan (agent) akan berusaha untuk melaporkan jumlah pajak yang relatif lebih kecil dengan cara melakukan penghindaran pajak, sedangkan principal menginginkan jumlah pajak yang dibayarkan perusahaan besar,

Hal tersebut sejalan dengan penelitian Satyadini (2018), Silvia (2017), dan Mahanani, Titisari \& Nurlaela (2017) yang mendapatkan hasil bahwa umur perusahaan berpengaruh negatif terhadap ETR/berpengaruh positif terhadap praktik penghindaran pajak. Berdasarkan hasil tersebut, hipotesis yang diambil dalam penelitian ini adalah:

H2: Umur perusahaan berpengaruh positif terhadap penghindaran pajak

\section{Pengaruh pertumbuhan penjualan terhadap penghindaran pajak}

Pertumbuhan penjualan menggambarkan perubahan pejualan antar periode dan mencerminkan prospek perusahaan di masa mendatang sehingga dapat dijadikan alat untuk memprediksi keuntungan (Dewinta \& Setyawan, 2016). Perusahaan yang mengalami peningkatan penjualan akan memperoleh laba yang besar. Besarnya laba perusahaan sebanding dengan jumlah beban pajak yang ditanggung perusahaan. Peningkatan beban pajak akan mendorong perusahaan untuk menekan beban pajak dengan melakukan penghindaran pajak dan nilai ETR perusahaan menjadi rendah.

Perbedaan kepentingan antara fiskus dan perusahaan akan memunculkan agency problem di mana fiskus sebagai principal (penerima pajak) menginginkan penerimaan pajak yang sebesar-besarnya, sedangkan perusahaan sebagai agent menginginkan pembayaran pajak seminimal mungkin kepada negara. Wajib pajak melakukan usaha untuk mengatur jumlah pajak yang harus dibayarkan, salah satunya melalui penghindaran pajak.

Penelitian yang dilakukan Budiman \& Setiyono (2012), Tristianto \& Oktaviani (2016), Dewinta \& Setiawan (2016), Purwanti \& Sugiyarti (2017), dan Silvia (2017) memperoleh hasil bahwa pertumbuhan penjualan berpengaruh negatif terhadap ETR yang artinya memiliki pengaruh positif terhadap penghindaran pajak. Perusahaan berusaha untuk melakukan penghematan pajak. Berdasarkan penelitian terdahulu dan fenomena yang terjadi, hipotesis dalam penelitian ini adalah:

H3: Pertumbuhan penjualan berpengaruh positif terhadap penghindaran pajak

\section{Pengaruh kepemilikan manajerial ter-} hadap penghindaran pajak

Kepemilikan saham oleh manajemen akan mengurangi masalah keagenan antara manajer (agent) dan pemegang saham (principal). Kepemilikan manajerial dapat menggambarkan adanya keselarasan kepentingan antara agent dan principal. Kepemilikan saham oleh manajemen mampu menekan tingkat penghindaran pajak dan meningkatkan angka ETR dikarenakan keputusan yang diambil akan berdampak terhadap entitas yang dimilikinya. (Winata, 2014).

Penelitian yang dilakukan antara lain Charisma \& Dwimulyani (2019), Budiarti (2017), dan Pramudito \& Sari (2015) yang menyatakan bahwa kepemilikan manajerial berpengaruh positif terhadap ETR/ menurunkan praktik penghindaran pajak. Keterlibatan manajer dalam kepemilikan saham diharapkan dapat efektif meningkat- 
kan kinerja manajemen dan dapat mengurangi perilaku manajemen dalam mementingkan kepentingan diri sendiri (Winata, 2014). Berdasarkan penelitian terdahulu dan fenomena yang terjadi, hipotesis dalam penelitian ini adalah:

H4: Kepemilikan manajerial berpengaruh negatif terhadap penghindaran pajak

\section{METODE PENELITIAN}

\section{Ruang Lingkup dan Objek Penelitian}

Populasi dalam penelitian ini adalah perusahaan non-jasa yang terdaftar pada BEI yang terdiri dari sektor A (perusahaan pertanian dan pertambangan) serta sektor B (perusahaan manufaktur). Sampel dalam penelitian ini yaitu industri non-jasa yang terdaftar pada BEI selama tahun 2014 sampai dengan tahun 2018 yang memenuhi kriteria sampling. Perusahaan ini dipilih karena masih banyaknya kasus penghindaran pajak yang terindikasi dari jenis industri tersebut. Non-jasa merupakan industri dengan tingkat ekspor dan impor yang tinggi sehingga kecenderungan untuk melakukan penghindaran pajak lebih agresif.

Perusahan non-jasa terdiri dari lima sub sektor, yaitu agriculture, basic industry and chemical, consumer goods industry, Mining, dan miscellaneous industry. Metode pengambilan sampel dalam penelitian ini menggunakan non probability sampling dengan teknik purposive sampling (Widarjono, 2015). Adapun kriteria-kriteria dalam pemilihan sampel yang dilakukan dalam penelitian ini, berikut kriteria yang harus dipenuhi yaitu: 1) Perusahaan industri non jasa yang terdaftar pada BEI periode 2014-2018. 2) Perusahaan tidak mengalami kerugian dalam periode 20142018 3) Effective Tax Rate (ETR) perusahaan negatif. 4) Perusahaan sampel tidak menggunakan mata uang asing dalam pelaporan keuangan. 5) Laporan keuangan lengkap selama periode penelitian.

\section{Teknik Pengumpulan Data}

Penelitian ini menggunakan data sekunder, yaitu berupa data laporan keuangan perusahaan non-jasa tahun 2014-2018 yang diperoleh melalui situs resmi BEI yaitu www.idx.co.id atau dari situs resmi perusahaan. Penggunaan periode tahun 2014 sampai dengan 2018 karena pada periode tahun tersebut terdapat kebijakan pemerintah berupa Tax Amnesty yang memberikan kesempatan bagi perusahaan untuk merevisi laporan total aset yang dimiliki tanpa dibebani denda pajak. Sehingga penelitian ingin melihat apakah dengan adanya kebijakan tersebut akan menghasilkan hasil penelitian yang berbeda dengan penelitian sebelumnya.

\section{Definisi Operasional dan Pengukuran Va- riabel}

\section{ETR (Effective Tax Rate)}

Variabel dependen dalam penelitian ini adalah ETR (Effective Tax Rate). ETR merupakan metode akuntansi untuk mengukur tarif ideal pajak perusahaan yang dihitung menggunakan rasio beban pajak penghasilan terhadap laba sebelum pajak. Proksi ini seringkali digunakan sebagai alat untuk mengukur penghindaran pajak dalam berbagai penelitian tentang perpajakan karena dapat menggambarkan strategi penangguhan dan ketidaksesuaian beban pajak (Hanlon dan Heitzman, 2010). Penggunaan ETR diharapkan mampu memberikan gambaran secara menyeluruh mengenai beban pajak yang akan berdampak pada laba akuntansi.

\section{Ukuran Perusahaan}

Menurut Machfoedz (1994) ukuran perusahaan dapat dihitung menggunakan berbagai cara, yaitu total aset perusahaan, jumlah penjualan, rerata tingkat penjualan, nilai pasar saham dan lain sebagainya. Variabel ukuran perusahaan dalam penelitian ini dilambangkan dengan "SIZE". Perhitungan ukuran perusahaan menggunakan logaritma natural (Ln) total aset. Menurut penelitian Surbakti (2010) proksi logaritma total aset mencerminkan nilai aktiva yang lebih stabil dan cenderung berkesinambungan antar periode dibandingkan dengan tingkat penjualan dan nilai kapitalisasi pasar. Proksi ini juga dapat mengurangi pergerakan data signifikan atau berlebih dan dapat menyederhanakan satuan nilai aset tanpa mengubah proporsi dan nilai asetnya.

SIZE $=$ Ln Total Aset 


\section{Umur Perusahaan}

Umur perusahaan melambangkan kemampuan perusahaan untuk bersaing dan bertahan di dunia bisnis. Menurut Ulum (2009) dalam umur perusahaan diukur sejak perusahaan terdaftar di BEI sampai laporan tahunan diterbitkan atau dihitung dengan menselisihkan tahun penelitian dengan tahun pertama kali perusahaan terdaftar di BEI. Umur perusahaan dalam penelitian ini dilambangkan dengan variabel AGE. AGE= Tahun penelitian sampai dengan tahun listing di BEI.

\section{Pertumbuhan Penjualan}

Pertumbuhan penjualan menunjukan kemampuan perusahan dalam rangka meningkatkan penjualannya dibagi dengan total penjualan secara keseluruhan (Kasmir, 2012:107). Pertumbuhan penjualan dalam penelitian ini diukur dengan rasio penjualan tahun berjalan dikurangi penjualan tahun sebelumnya dan dibagi dengan penjualan tahun sebelumnya (Fahmi, 2012). Pertumbuhan penjualan pada penelitian ini dilambangkan dengan SG (Sales Growth).

$\mathrm{SG}=\left(\right.$ Penjualan $_{\mathrm{t}}$ Penjualan $\left._{\mathrm{t}-1}\right) /$ Penjualan $_{\mathrm{t}-1}$

\section{Kepemilikan Manajerial}

Kepemilikan manajerial merupakan kepemilikan saham yang dimiliki oleh manajemen memenuhi persyaratan tertentu untuk memiliki saham. Persentase kepemilikan saham oleh manajemen mengindikasikan adanya kesamaan tujuan antara perusahaan dan pemegang saham.
Peran ganda dari manajemen berdampak pada pengambilan keputusan yang lebih hati-hati sehingga mampu menengahi konflik keagenan. Penelitian ini mengukur kepemilikan manajerial menggunakan persentase antara jumlah saham yang dimiliki oleh manajemen dengan jumlah saham yang beredar (Munisi et al., 2014). Kepemilikan manajerial pada penelitian ini dilambangkan dengan MO (Managerial Ownership). $\mathrm{MO}=($ Jumlah saham yang dimiliki manajemen)/(Jumlah saham beredar)

\section{Teknik Analisis Data}

Penelitian ini menggunakan analisis deskriptif dan pengujian hipotesis dengan menggunakan uji regresi linear berganda. Model yang digunakan untuk menguji hipotesis adalah sebagai berikut:

$$
\begin{gathered}
\mathrm{ETR}=\alpha+\beta 1 \text { SIZE }+\beta 2 \mathrm{AGE}+\beta 3 \mathrm{SG}+\beta 4 \\
\mathrm{MO}+\varepsilon
\end{gathered}
$$

dimana ETR = Effetive Tax Rate; SIZE : Ukuran Perusahaan; AGE:Umur Perusahaan; SG: Pertumbuhan Penjualan; dan MO: Kepemilikan Manajerial

\section{ANALISIS DAN PEMBAHASAN \\ Sampel Penelitian}

Sampel penelitian adalah perusahaan non jasa yang terdaftar di BEI pada periode 2014-2018. Metode pengambilan sampel pada penelitian ini menggunakan teknik purposive sampling seperti Tabel 1.

Berdasarkan data yang diperoleh melalui website resmi BEI bahwa pada tahun 2014-2018 terdapat 258 perusahaan non jasa yang terdaftar tiap tahunnya. Sampel

Tabel 1

\begin{tabular}{|c|c|}
\hline Kriteria Sampel & Jumlah \\
\hline $\begin{array}{l}\text { Perusahaan non jasa yang terdaftar di BEI pada tahun 2014-2018 } \\
\text { Perusahaan non jasa yang terdaftar di BEI yang laporan keuangannya tidak } \\
\text { lengkap dan tidak diperoleh selama periode } 2014-2018\end{array}$ & $\begin{array}{l}258 \\
(42)\end{array}$ \\
\hline $\begin{array}{l}\text { Perusahaan non jasa yang terdaftar di BEI dengan laba sebelum pajak } \\
\text { negatif selama periode } 2014-2018\end{array}$ & $(107)$ \\
\hline $\begin{array}{l}\text { Perusahaan non jasa yang terdaftar di BEI dengan satuan mata uang asing } \\
\text { selama periode 2014-2018 }\end{array}$ & (37) \\
\hline $\begin{array}{l}\text { Jumlah sampel perusahaan yang digunakan periode pengamatan } \\
\text { penelitian }\end{array}$ & $\begin{array}{c}73 \\
5 \\
365\end{array}$ \\
\hline Data Outlier & $(83)$ \\
\hline Jumlah data observasi & 282 \\
\hline
\end{tabular}

Kriteria Pengambilan Sampel 
akhir penelitian ini berjumlah 73 yang terdiri dari 4 perusahaan agriculture, 23 perusahaan basic industry and chemicals, 25 perusahaan consumer coods industry, 5 Perusahaan Mining, dan 16 Perusahaan Miscellaneous Industry setiap tahunnya atau 282 data observasi yang digunakan selama 5 tahun.

Berdasarkan hasil uji statistik deskriptif pada Tabel 2, Variabel dependen (ETR) memiliki nilai minimum 0,01 yaitu dari PT Semen Indonesia Tbk (SMGR) pada tahun 2018 dan nilai maksimum 0,97121 yaitu dari PT Buana Artha Anugerah Tbk (STAR) pada tahun 2018. Nilai ETR memiliki rata-rata 0,2716 serta standar deviasi sebesar 0,10647. Hasil rerata ETR yang lebih tinggi dari standar deviasi menjelaskan bahwa penghindaran pajak yang agresif pada perusahaan non-jasa masih dimungkinkan terjadi. Kondisi ini relevan dengan banyaknya potensi pajak yang hilang dari sektor non-jasa.

Variabel ukuran perusahaan (SIZE) memiliki nilai maksimum sebesar 33.47 yang dimiliki oleh PT Astra International Tbk (ASII) pada tahun 2018. Nilai minimum sebesar 25,62 yang dimiliki oleh PT Lionmesh Prima Tbk (LMSH) pada tahun 2015. Standar deviasi sebesar 1,64271 , dan nilai rata-rata sebesar 28,7659 . Hasil ratarata menunjukkan bahwa mayoritas perusahaan non-jasa memiliki total aset yang besar. Total aset yang besar menggambarkan karakteristik perusahaan yang semakin kompleks dan sumber daya yang lebih besarnya sehingga mempunyai banyak celah untuk menekan beban pajak.

Variabel umur perusahaan (AGE) memiliki nilai maksimum sebesar 37 oleh PT Merck Tbk (MERK) pada tahun 2018. Nilai minimum sebesar 1 oleh PT Impack Pratama Industri Tbk (IMPC) pada tahun 2015. Standar deviasi sebesar 9,27614 dan memiliki nilai rata-rata sebesar 18,8830 . Hasil rerata umur perusahaan menunjukkan bahwa sebagai besar perusahaan sampel merupakan pemain yang cukup lama dalam dunia bisnis. Jangka waktu yang lama menjadikan perusahaan lebih berpengalaman dan ahli dalam menghadapi kendala yang terjadi. Variabel pertumbuhan penjualan (SG) memiliki nilai maksimum sebesar 0,54 yang diperoleh PT Wijaya Karya Beton (WTON) pada tahun 2017. Nilai minimum sebesar $-0,50$ diperoleh PT Buana Artha Anugerah Tbk (STAR) pada tahun 2016. Standar deviasi sebesar 0,12689 dan memiliki nilai rata rata sebesar 0,0721 . Nilai rerata pertumbuhan penjualan menunjukkan bahwa mayoritas perusahaan sampel mengalami pertumbuhan penjualan yang sangat kecil atau hanya sebesar 7,21\%. Fenomena tersebut mendorong manajemen untuk bisa melakukan efisiensi beban perusahaan, salah satunya adalah efisiensi beban pajak.

Variabel kepemilikan manajerial (MO) memiliki nilai maksimum sebesar 0,81000 yang dimiliki PT Industri Jamu dan Farmasi Sido Muncul Tbk (SIDO) pada tahun 2017. Nilai minimum sebesar 0,00000 dimiliki PT Wijaya Karya Beton (WTON) pada tahun 2017. Standar deviasi sebesar 0,11113 , dan memiliki nilai rata-rata sebesar 0,0460 . Hasil rerata menunjukkan bahwa proporsi rata-rata kepemilikan saham manajerial sangat rendah dibandingkan dengan struktur kepemilikan lainnya. Rendahnya persentase kepemilikan manajerial melambangkan kecilnya pengaruh manajemen sebagai pemegang saham

Tabel 2

Hasil Statistik Deskriptif

\begin{tabular}{cccccc}
\hline Variabel & $\mathrm{n}$ & Mean & Maksimum & Mininum & Standar Deviasi \\
\hline ETR & 282 & 0.2716 & 0.9721 & 0.01 & 0.10647 \\
SIZE & 282 & 28.7659 & 33.47 & 25.62 & 1.64271 \\
AGE & 282 & 18.8830 & 37.00 & 1.00 & 9.27614 \\
SG & 282 & 0.0721 & 0.54 & -0.50 & 0.12689 \\
MO & 282 & 0.0460 & 0.81 & 0.00 & 0.11113 \\
\hline
\end{tabular}


dalam pengambilan keputusan perusahaan.

\section{Pengujian Hipotesis}

Pada penelitian ini uji hipotesis menggunakan tiga pengujian, yaitu koefisien determinasi (R2), uji signifikansi simultan (Uji F), dan uji signifikansi parameter individual (Uji statistik T).

Berdasarkan Tabel 3, dapat dilihat bahwa nilai Adjusted R Square untuk model regresi pada penelitian ini adalah sebesar 26,7\%. Hasil ini dapat dikatakan bahwa sebesar 26,7\% variabel dependen yakni ETR dapat dijelaskan dari variabel independen yang ada yakni SIZE, AGE, SG dan MO pada perusahaan sampel. Sedangkan sisanya yakni 73,3\% merupakan faktor-faktor lain di luar dari variabel independen yang digunakan.

Hasil uji signifikansi simultan menunjukkan bahwa nilai signifikansi sebesar 0,000. Hasil tersebut kurang dari $\alpha=0,05$ atau dapat dikatakan model regresi yang digunakan pada penelitian ini dapat mempengaruhi variabel dependen secara simultan atau bersama-sama dan layak digunakan untuk memprediksi variabel dependen pada perusahaan sampel.

\section{Uji Statistik t}

Hasil pengujian ini dapat dilihat pada Tabel 3. Berdasarkan tabel hasil uji statistik t di atas, dapat dijelaskan ukuran perusahaan (SIZE) memiliki nilai signifikansi sebesar 0,000 lebih kecil dari $\alpha(0,05)$ dan nilai koefisien sebesar -0,013. Nilai tersebut menjelaskan bahwa SIZE berpengaruh

Tabel 3

Hasil Uji Statistik t

\begin{tabular}{lccc}
\hline & $\mathrm{B}$ & $\begin{array}{c}\text { Std. } \\
\text { Error }\end{array}$ & Sig. \\
\hline (Constant) & 0,713 & 0,099 & 0,000 \\
SIZE & $-0,013$ & 0,003 & 0,000 \\
AGE & $-0,001$ & 0,001 & 0,014 \\
SG & $-0,384$ & 0,043 & 0,000 \\
MO & $-0,069$ & 0,051 & 0,177 \\
\multicolumn{2}{c}{ Adj, R ${ }^{2}: 0.267$} & & \\
\hline
\end{tabular}

negatif terhadap ETR pada perusahan yang masuk dalam sampel penelitian. Hal ini berarti semakin besar ukuran suatu perusahaan memiliki kecenderungan mempunyai nilai ETR yang rendah (semakin kecil nilai ETR menunjukkan perencanaan pajak yang semakin agresif karena perusahaan berusaha menekan beban pajak terhadap laba sebelum pajak). Hal tersebut sesuai dengan hipotesis pertama sehingga $\mathrm{Hl}$ didukung.

Umur perusahaan (AGE) yang memiliki tingkat signifikansi 0,014 atau lebih kecil dari $\alpha(0,05)$ dengan nilai koefisien 0,001 terhadap ETR pada sampel penelitian. Hal ini berarti semakin lama umur perusahaan, memiliki kecenderungan mempunyai nilai ETR yang rendah. Sehingga umur perusahaan yang semakin tinggi akan meningkatkan praktik penghindaran pajak yang dilakukan oleh perusahaan. Hal tersebut sesuai dengan hipotesis kedua sehingga $\mathrm{H} 2$ didukung.

Pertumbuhan penjualan (SG) yang memperoleh nilai signifikansi sebesar 0,000 lebih kecil dari $\alpha(0,05)$ dengan nilai koefisien negatif sebesar 0,384 terhadap ETR pada sampel penelitian. Hal ini berarti dapat dikatakan perusahaan yang memiliki angka pertumbuhan penjualan yang lebih tinggi memiliki kecenderungan mempunyai nilai ETR yang rendah. Hasil tersebut sesuai dengan hipotesis ketiga sehingga H3 didukung.

Kepemilikan manajerial (MO) yang memiliki nilai signifikansi sebesar 0,177 atau lebih besar dari $\alpha(0,05)$ dengan nilai koefisien yang negatif sebesar -0,069 terhadap ETR pada sampel penelitian. Nilai tersebut tidak sesuai dengan hipotesis keempat sehingga $\mathrm{H}_{4}$ tidak didukung.

\section{ANALISIS DAN PEMBAHASAN Pengaruh ukuran perusahan terhadap penghindaran pajak}

Semakin besar perusahaan, maka ETR yang dihasilkan semakin kecil. ETR yang kecil mengindikasikan perencanaan pajak yang agresif. Hasil ini sesuai dengan Dewinta dan Setyawan (2016), Darmawan dan Sukarta (2014), dan Fatharani (2012) yang menyatakan bahwan ukuran perusahaan berpengaruh negatif terhadap ETR/ berpengaruh positif terhadap praktik 
penghindaran pajak.

Perusahaan besar akan memiliki pengelolaan sumber daya yang melimpah. Hal tersebut sebanding dengan besarnya beban yang akan ditanggung oleh perusahaan. Manajer memanfaatkan sumber daya yang dimiliki oleh perusahaan untuk mengoptimalkan kompensasi kinerja, salah satunya dengan cara menekan beban pajak perusahaan untuk mencapai kinerja perusahaan yang optimal. Penjelasan yang sama juga terdapat dalam teori kekuasaan politik yang menyatakan bahwa perusahaan yang berukuran besar cenderung lebih agresif dalam melakukan penghindaran pajak. Perusahaan menggunakan sumber daya yang dimiliki untuk memengaruhi kebijaksanaan umum (pemerintah) untuk memperoleh keuntungan termasuk melakukan aktivitas penghindaran pajak (Dewinta \& Setyawan, 2016). Ukuran perusahaan yang semakin besar berbanding lurus dengan aktivitas operasional yang semakin kompleks. Kompleksitas pada perusahaan dijadikan kesempatan oleh manajemen untuk mencari celah dalam melakukan perencanaan pajak. Salah satu contohnya adalah penggunaan metode akuntansi untuk menangguhkan laba saat ini pada periode mendatang untuk memperoleh beban pajak yang lebih rendah (Zimmerman, 1983). Selain itu perusahaan besar dalam melakukan aktivitas perencanaan pajak cenderung memanfaatkan celah dalam peraturan perpajakan, seperti mekanisme transfer pricing dan treaty shopping yang banyak dilakukan oleh perusahaan multinasional yang ada di Indonesia (Rusydi, 2014).

\section{Pengaruh umur perusahan terhadap penghindaran pajak}

Hasil uji t pada sampel penelitian untuk pengaruh umur perusahaan pada penghindaran pajak menunjukkan nilai koefisien sebesar -0,001 dengan tingkat signifikansi 0.014 atau signifikan pada $\alpha=$ 5\%. Semakin lama umur perusahaan, maka ETR yang dihasilkan semakin kecil. ETR yang kecil mengindikasikan perencanaan pajak perusahaan yang agresif dan cenderung menekan beban pajak perusahaan. Hasil ini sejalan dengan penelitian Mahanani et al. (2017), Silvia (2017), dan Dewinta \& Setiawan (2016) yang menyimpulkan bahwa umur perusahaan berpengaruh signifikan negatif terhadap ETR/berpengaruh positif terhadap penghindaran pajak.

Penelitian Loderer \& Waelchli (2010) menjelaskan bahwa perusahaan mengalami profitabilitas yang menurun seiring dengan berjalannya waktu. Entitas menjadi kurang efisien dibandingkan dengan perusahaan lain dalam industri yang sama, seperti yang ditunjukkan oleh margin yang lebih rendah, biaya yang lebih tinggi, pertumbuhan yang lebih lambat, dan mengurangi kegiatan R\&D. Selain itu, entitas yang menua dihadapkan pada beban perusahaan yang semakin kompleks. Sehingga perusahaan dituntut untuk mampu mengelola beban seefisien mungkin termasuk beban pajaknya.

Pengalaman dan pembelajaran yang dimiliki perusahaan dari waktu ke waktu membentuk manajemen yang lebih ahli dan kritis dalam pengelolaan pajak perusahaan. Perusahaan menggunakan keahlian, pengalaman, dan semua informasi yang dimiliki manajemen untuk menekan beban pajak sehingga kewajiban pajak perusahaan menjadi sangat efisien. Studi lain yang dilakukan oleh Dyreng, Hanlon \& Maydew (2008) menjelaskan bahwa perusahaan memanfaatkan umur perusahaan untuk menunda atau bahkan menghindari kewajiban pajaknya dalam waktu yang lama.

\section{Pengaruh pertumbuhan penjualan ter- hadap penghindaran pajak.}

Hasil uji $t$ pada sampel penelitian menunjukkan nilai koefisien negatif sebesar 0,384 dan nilai signifikansi sebesar 0,000 atau signifikan pada $\alpha=0,5$. Nilai koefisien yang negatif menunjukkan hubungan yang berbanding terbalik antara ETR dan pertumbuhan penjualan. Semakin tinggi rasio pertumbuhan penjualan, maka nilai ETR semakin kecil. ETR yang kecil mengindikasikan tingginya penghindaran pajak perusahaan sehingga dapat disimpulkan bahwa pertumbuhan penjualan berpengaruh negatif terhadap ETR/berpengaruh positif terhadap 
penghindaran pajak. Penelitian ini sejalan dengan penelitian yang dilakukan oleh Silvia (2017), Dewinta \& Setyawan (2016), dan Budiman \& Setiyono (2012).

Meningkatnya pertumbuhan penjualan akan berdampak pada laba perusahaan yang semakin besar. Hal tersebut berbanding lurus dengan besarnya beban pajak yang harus di tanggung perusahaan. Berdasarkan fenomena tersebut mendorong manajemen untuk menekan besarnya beban pajak sehingga kompensasi kinerja yang diterima tidak akan berkurang seiring laba perusahaan yang meningkat. Selain itu, pengoptimalan pajak yang dilakukan oleh manajemen bertujuan untuk memaksimalkan nilai perusahaan dan meningkatkan total aset perusahaan.

\section{Pengaruh kepemilikan manajerial ter- hadap penghindaran pajak.}

Berdasarkan uji t pada sampel penelitian antara kepemilikan manajerial dan penghindaran pajak menunjukkan nilai koefisien sebesar 0,0239678 dan tingkat signifikansi 0,780 . Nilai tersebut menjelaskan bahwa tidak ada hubungan signifikan antara kepemilikan manajerial dan ETR. Hasil ini senada dengan penelitian Mahulae et al. (2016) dan Hadi \& Mangoting (2014) yang menjelaskan tidak ada pengaruh antara kepemilikan manajerial dan ETR.

Kepemilikan manajerial yang tidak berpengaruh terhadap penghindaran pajak disebabkan oleh kecilnya peran dalam pengambilan keputusan perusahaan. Persentase kepemilikan manajerial yang rendah membatasi wewenang dan kesempatan manajerial dalam perusahaan. Hasil penelitian ini juga menggambarkan bahwa rata-rata kepemilikan manajerial dari seluruh sampel perusahaan sangat kecil yaitu sebesar 4,5\% dari total saham yang beredar.

Kepemilikan manajerial merupakan salah satu upaya untuk mengurangi konflik keagenan. Manajemen yang bertindak sebagai agent juga memiliki peran sebagai principal atas proporsi saham yang dimiliki dalam perusahaan. Adanya fenomena tersebut mendorong pihak manajemen untuk berupaya memaksimalkan kinerjanya da- lam rangka memenuhi keinginan pemegang saham yang tidak lain adalah dirinya sendiri. Manajemen akan lebih berhati-hati dalam mengambil keputusan dalam perusahaan karena keputusan yang salah akan berdampak besar kepada manajemen baik sebagai agent maupun principal. Oleh karena itu, dengan adanya kepemilikan manajerial, manajemen cenderung menghindari perencanaan pajak yang agresif karena dikhawatirkan dapat memperburuk nilai perusahaan di masa mendatang.

\section{SIMPULAN}

Tujuan penelitian ini adalah untuk menguji pengaruh ukuran perusahaan, umur perusahaan, pertumbuhan penjualan, dan kepemilikan manajerial terhadap penghindaran pajak yang diproksikan dengan ETR. Hasil penelitian dapat disimpulkan sebagai berikut:

Variabel ukuran perusahaan berpengaruh negatif terhadap ETR pada perusahaan non-jasa yang terdaftar di BEI selama periode 2014-2018 yang masuk dalam kategori sampel penelitian, yang artinya ukuran perusahaan berpengaruh positif terhadap praktik penghindaran pajak. Semakin besar ukuran perusahaan, celah untuk melakukan penghindaran pajak oleh perusahaan juga semakin besar.

Variabel umur perusaahan berpengaruh positif terhadap praktik penghindaran pajak pada perusahaan non -jasa yang terdaftar di BEI selama periode 2014-2018 yang masuk dalam kategori sampel penelitian. Artinya, semakin lama periode perusahaan di bursa efek akan sebanding dengan kecenderungan untuk memperoleh ETR yang rendah atau adanya aktivitas penghindaran pajak yang agresif.

Variabel pertumbuhan penjualan berpengaruh positif terhadap penghindaran pajak pada perusahaan non -jasa yang terdaftar di BEI selama periode 2014-2018 yang masuk dalam kategori sampel penelitian. Pertumbuhan penjualan yang tinggi berbanding lurus dengan agresivitas penghindaran pajak perusahaan. Perusahaan dengan pertumbuhan yang tinggi berusaha untuk menekan biaya pajaknya seefektif mungkin sehing- 
ga laba perusahaan tidak berubah signifikan dengan adanya beban pajak.

Variabel kepemilikan manajerial tidak berpengaruh terhadap besarnya ETR pada perusahaan non-jasa yang terdaftar di BEI selama periode 2014-2018 yang masuk dalam kategori sampel penelitian. Persentase kepemilikan yang kecil membatasi wewenang manajemen dalam pengambilan keputusan. Hasil penelitian menunjukkan pengaruh secara keseluruhan pada perusahaan yang menjadi sampel penelitian dan tidak dapat dijadikan acuan untuk melihat pengaruh pada masing-masing perusahaan secara individual.

\section{KETERBATASAN DAN SARAN}

Pada penelitian ini, peneliti masih menemukan beberapa keterbatasan. Pertama, Sampel pada penelitian ini hanya terfokus pada perusahaan non jasa pada rentang waktu 2014-2018. Kedua, Proksi ETR tidak dapat membedakan perbedaan antara agresivitas perencanaan pajak, preferensi pajak pemerintah, atau kegiatan lobi perpajakan dan tidak melambangkan besar pajak sesungguhnya yang dibayar perusahaan berdasarkan laba pada tahun berjalan. Ketiga, Variabel yang diteliti hanya menggunakan variabel ukuran perusahaan, umur perusahaan, pertumbuhan penjualan, dan kepemilikan manajerial yang memiliki pengaruh sangat kecil terhadap penghindaran pajak.

Saran untuk penelitian selanjutnya dapat menambah rentang waktu penelitian. Kedua, dapat menggunakan proksi yang dapat menggambarkan besarnya beban pajak yang dibayarkan perusahaan sehingga dapat menjelaskan lebih dalam mengenai agresivitas perencanaan pajak perusahaan. Ketiga, Penelitian selanjutnya dapat menambah atau menggunakan variabel independent lainnya, sehingga dapat memperoleh pengaruh yang lebih besar antara variabel $x$ dengan variabel $y$.

\section{DAFTAR PUSTAKA}

Budiarti, S. (2017). Pengaruh good corporate governance terhadap tax avoidance (Studi empiris pada sektor perbankan yang terdaftar di BEI periode 2014-2016). Jurnal Akuntansi,
$1-12$.

Budiman, J., \& Setiyono (2012). Pengaruh karakter eksekutif terhadap penghindaran pajak (Tax avoidance). Paper dipresentasikan pada acara Simposium Nasional Akuntansi $\mathrm{XV}$, Banjarmasin.

Charisma, R.B., \& Dwimulyani, S. (2019, April). Pengaruh struktur kepemilikan terhadap tindakan penghindaran pajak dengan kualitas audit sebagai variabel moderating. Prosiding Seminar Nasional Pakar, 2-32.

Darussalam. (2017, November 19). Apa itu BEPS?. Diakses dari https:// news.ddtc.co.id/

DDTC Fiscal Research. (2017, April 20). Memahami arti tax ratio. Diakses dari https://news.ddtc.co.id/

Dewinta, I.A.R., \& Setiawan, P.E. (2016). Pengaruh ukuran perusahaan, umur perusahaan, profitabilitas, leverage, dan pertumbuhan penjualan terhadap tax avoidance. E-Jurnal Akuntansi, 1584-1615.

Direktorat Jenderal Pajak. (2018). Laporan Kinerja Direktorat Jenderal Pajak (LAKIN DJP). Direktorat Jenderal Pajak.

Dyreng, S.D., Hanlon, M., \& Maydew, E.L. (2008). Long-run corporate tax avoidance. The accounting review, 83 (1), 61-82.

Fahmi, I. (2012). Analisis laporan keuangan. Bandung: Alfabeta.

Fatharani, N. (2012). Pengaruh Karakterisitik kepemilikan, reformasi perpajakan, dan hubungan politik terhadap tindakan pajak agresif pada perusahaan yang terdaftar di Bursa Efek Indonesia pada tahun 2007-2010 (Skripsi). Universitas Indonesia, Depok.

Hadi, J., \& Mangoting, Y. (2014). Pengaruh Struktur Kepemilikan dan Karakteristik Dewan Terhadap Agresivitas Pajak. Tax \& Accounting Review, 4(2).

Hanlon, M., \& Heitzman, S. (2010). A Review of Tax Research. Journal of Accounting and Economics, 50, 127-178

Ihyaul, U. (2009). Intellectual capital: Konsep dan kajian empiris. Yogyakarta: Graha Ilmu.

Hutagaol, J. (2007). Perpajakan: Isu-isu kontemporer. Yogyakarta: Graha Ilmu

Kasmir. 2012. Analisis laporan keuangan. Jakarta: PT Raja Grafindo Persada. 
Media Keuangan Transparansi Informasi Kebijakan Fiskal. (2019). Kementerian Keuangan, 16(138).

Kurniasih, T., \& Sari, M.M.R. (2013). Pengaruh return on assets, leverage, corporate governance, ukuran perusahaan dan kompensasi rugi fiskal pada tax avoidance. Buletin Studi Ekonomi, 18(1).

Loderer, C.F., \& Waelchli, U. (2010). Firm age and performance. Available at SSRN 1342248.

Machfoedz, M.U. (1994). Financial ratio analysis and the prediction of earnings changes in Indonesia. Kelola, 7(3), 114-134.

Mahanani, A., Titisari, K.H., \& Nurlaela, S. (2017). Pengaruh karakteristik perusahaan, sales growth dan csr terhadap tax avoidance. Paper dipresentasikan pada acara Seminar Nasional IENACO - 2017

Mahulae, E.E., Pratomo, D., \& Nurbaiti, A. (2016). Pengaruh kepemilikan institusional, kepemilikan manajerial dan komite audit terhadap tax avoidance (Studi pada perusahaan otomotif yang terdaftar di Bursa Efek Indonesia tahun 2010-2014). eProceedings of Management, 3(2).

Munisi, G., Hermes, N., \& Randøy, T. (2014). Corporate boards and ownership structure: Evidence from Sub-Saharan Africa. International Business Review, 23(4), 785-796.

Nugraheni, A.S., \& Pratomo, D. (2018). Pengaruh komite audit, kualitas audit, dan ukuran perusahaan terhadap tax avoidance (Studi pada perusahaan non jasa subsektor otomotif yang terdaftar di Bursa Efek Indonesia Tahun 2012-2016). eProceedings of Management, 5(2).

Oktaviyani, R., \& Munandar, A. (2017). Effect of solvency, sales growth, and institutional ownership on tax avoidance with profitability as moderating variables in Indonesian Property and Real Estate Companies. Binus Business Review, 8(3), 183-188.

Pramudito, B.W., \& Sari, M.M.R. (2015). Pengaruh konservatisme akuntansi, kepemilikan manajerial dan ukuran dewan komisaris terhadap tax avoidance. E-Jurnal Akuntansi Universitas Udayana, 13(3), 705-722.

Permata, A.D., Nurlaela, S., \& Masitoh, E. (2018). Pengaruh size, age, profitability, leverage dan sales growth terhadap tax avoidance. Jurnal Akuntansi dan Pajak, 19(01),
10-20.

Purwanti, S.M., \& Sugiyarti, L. (2017). Pengaruh intensitas aset tetap, pertumbuhan penjualan dan koneksi politik terhadap tax avoidance (Studi kasus pada perusahaan manufaktur yang terdaftar di Bursa Efek Indonesia tahun 2012-2016). Jurnal Riset Akuntansi dan Keuangan, 5(3), 1625-1642.

Richardson, G., \& Lanis, R. (2007). Determinants of the variability in corporate effective tax rates and tax reform: Evidence from Australia. Journal of accounting and public policy, 26(6), 689-704.

Rusydi, M.K. (2014). Pengaruh ukuran perusahaan terhadap aggressive tax avoidance di Indonesia. Jurnal Akuntansi Multiparadigma, 4(2), 323329.

Gaaya, S., Lakhal, N., \& Lakhal, F. (2017). Does family ownership reduce corporate tax avoidance? The moderating effect of audit quality. Managerial Auditing Journal.

Global Witness. 2019. Taxing Times for Adaro. Diakses dari https:// www.globalwitness.org/

Setianti, P. (2019). Pengaruh profitabilitas, leverage, umurperusahaan, intensitas modal dan kepemilikan manajerial terhadap penghindaran pajak (Disertasi). STIE Perbanas Surabaya, Surabaya.

Setiaji, H. (2019, November 26). Wow! Dikejar pajak, ada 563.360 pemilik saldo bank $R p$ 1M. Diakses dari https://www.cnbcindonesia.com/

Silvia, Y.S. (2017). Pengaruh manajemen laba, umur perusahaan, ukuran perusahaan, dan pertumbuhan penjualan terhadap tax avoidance. Jurnal Equity, 3(4).

Stiglitz, J.E. (1986). The general theory of tax avoidance (No. W1868). National Bureau of Economic Research.

Surbakti, T.A. (2010). Pengaruh corporate governance, profitabilitas dan karakteristik eksekutif pada tax avoidance perusahaan manufaktur (Skripsi). Univeritas Indonesia, Depok.

Swingly, C., \& Sukartha, I.M. (2015). Pengaruh karakter eksekutif, komite audit, ukuran perusahaan, leverage dan sales growth padatax avoidance. E-Jurnal Akuntansi, 47-62.

Tristianto, D., \& Oktaviani, R.M. (2016). Faktor-faktor yang mempengaruhi tax avoidance dengan leverage sebagai variabel mediasi. Dinamika Akuntansi 
Keuangan dan Perbankan, 5(1).

Wareza, M. (2019). Disebut terlibat transfer pricing Adaro, siapa coaltrade?. Dia k s s d a r i ht p s:// www.cnbcindonesia.com/

Widarjono, A. (2015). Analisis multivariat terapan. Yogyakarta: UPP STIM YKPN.

Wijayanti, A., Wijayanti, A., \& Samrotun, Y.C. (2016). Pengaruh karakteristik perusahaan, gcg dan csr terhadap penghindaran pajak. Journal of
Economic and Economic Education, 5 (2), 113-127

Winata, F. (2014). Pengaruh corporate governance terhadap tax avoidance pada perusahaan yang terdaftar di Bursa Efek Indonesia tahun 2013. Tax \& Accounting Review, 4(1), 162.

Zimmerman, J.L. (1983). Taxes and firm size. Journal of accounting and economics, 5, 119-149. 